\title{
Serosurvey for Assessment of Peste des Petits Ruminants Virus Antibodies Status in Sheep and Goats in the Rural System of Odisha State, India
}

\section{Shashikumar Sowjanyakumari ${ }^{1,2}$, Gurrappanaidu Govindaraj ${ }^{1}$, Gopal Bal $^{3}$, Bheemappa Matheshwara $^{1}$, Kirubakaran Vinod Kumar ${ }^{1}$, Mohandoss Nagalingam ${ }^{1}$, Siju Susan Jacob ${ }^{1}$, Bibek Ranjan Shome ${ }^{1}$, Vinayagamurthy Balamurugan ${ }^{1 *}$}

\begin{abstract}
${ }^{1}$ Indian Council of Agricultural Research -National Institute of Veterinary Epidemiology and Disease Informatics (ICAR-NIVEDI), Yelahanka, Bengaluru-560064, Karnataka, India; ${ }^{2}$ Department of Microbiology, Jain University, Bengaluru, Karnataka, India; ${ }^{3}$ Directorate of Animal Husbandry and Veterinary Services, Odisha, India.
\end{abstract}

\begin{abstract}
The serosurvey was carried out to determine the status of peste des petits ruminants virus (PPRV) antibodies in sheep and goats in the rural system of Odisha state, India. The serum samples were collected along with host parameters from various flocks in different epidemiological units in selected three districts in the study region from January to February 2021. A total of 363 serum samples [sheep $(n=130)$ and goats $(n=233)$ ] collected were screened by indigenous PPR competitive ELISA kit for the detection of PPRV antibodies. The results revealed that the observed prevalence of PPRV antibodies in sheep and goats was 92.0, 72.2, and 50.7\% in Balangir, Kalahandi, and Mayurbhanj districts, respectively. An overall $63.91 \%$ (95\% CI: 58.85-68.68) prevalence of antibodies were observed in small ruminants with $59.23 \%$ (95\% CI: $50.64-67.29)$ in sheep and $66.52 \%$ (95\% CI: $60.24-72.27$ ) in goats, as all the districts in Odisha adopted the PPR vaccination in both sheep and goats. Further, the results of the multivariable logistic regression analysis revealed that species and districts were significantly associated with the prevalence of PPRV antibodies. The observed seroconversion was near to the recommended (70-80\%) level by the world organization for animal health (OIE), which indicates the existing PPR vaccination strategy has provided desired protection levels. However, in the present study, only $60 \%$ of epi-units in three districts, had shown $>70 \%$ prevalence of PPRV antibodies, which demands further intensive vaccination coupled with active surveillance programs to make this region a PPR free zone. For that, the mass vaccination program needs to be adopted in line with the OIE and the national strategic plan for PPR eradication 2025, for elimination of PPRV from India.
\end{abstract}

Keywords | Serosurvey, PPR, Population immunity, ELISA, Small ruminants, Odisha, India

Received | September 16,2021; Accepted | October 25, 2021; Published | December 01, 2021

*Correspondence | Vinayagamurthy Balamurugan, Indian Council of Agricultural Research -National Institute of Veterinary Epidemiology and Disease Informatics (ICAR-NIVEDI), Yelahanka, Bengaluru-560064, Karnataka, India; Email: b.vinayagamurthy@icar.gov.in, balavirol@gmail.com

Citation | Sowjanyakumari S, Govindaraj G, Bal G, Matheshwara B, Kumar KV, Nagalingam M, Jacob SS, Shome BR, Balamurugan V (2022). Serosurvey for assessment of peste des petits ruminants virus antibodies status in sheep and goats in the rural system of Odisha State, India. Adv. Anim. Vet. Sci. 10(1): 1-7. DOI | http://dx.doi.org/10.17582/journal.aavs/2022/10.1.1.7

ISSN (Online) | 2307-8316; ISSN (Print) | 2309-3331

Copyright $(2022$ Sowjanyakumari et al. This is an open access article distributed under the Creative Commons Attribution License, which permits unrestricted use, distribution, and reproduction in any medium, provided the original work is properly cited.

\section{INTRODUCTION}

$\mathrm{P}$ este des petits ruminants (PPR) is a contagious, economically important, World Organization for Animal Health (OIE) notifiable, morbillivirus (small ruminant morbillivirus-SRMV) infecting disease of sheep and goats and other related wildlife small ruminants species. The disease causes the highest death among various infectious diseases that limit the optimum productivity of sheep and goats in the world. Most of the sheep and goats are reared by poor sections of rural communities for nutrition, livelihood, and financial needs 
(Balamurugan et al., 2021). The disease poses a serious threat to small ruminant production in Africa, Asia, and the Middle East, where the disease is widespread and endemic; hence the disease outbreak on small ruminants has a huge socio-economic impact on all the developing countries (Balamurugan et al., 2014, 2021; OIE and FAO, 2015; Yirga et al., 2020). Because of its increasing spread, it becomes a main constraint in augmenting the productivity of small ruminants in endemic countries. OIE has considered PPR as an economically important ruminants' disease and taken action to eradicate PPRV by 2030, as part of the OIE/FAO Global Strategic Plan (OIE and FAO, 2015). Vaccination is an important tool for the control of PPR in endemic developing countries like India because of the availability of effective and safe vaccines which provide long-lasting protection (OIE and FAO, 2015).

India is a vast country with a population of 148.88 million goats and 74.26 million sheep against a world population of $\sim 2$ billion small ruminants (Balamurugan et al., 2020b, 2021). Sheep and goats are the "Any Time Money" of the poor landless, marginal, and small farmers and they generate income and employment for their livelihood. The disease reporting, understanding of the disease epidemiology, strong support of diagnostics and surveillance, and vaccination of the animals are highly imperative for the effective control of disease, besides strategic plan and infrastructure facilities. India practiced focused vaccination in PPR outbreak places since 2002 and program mode since 2011 even before the global strategy was scheduled (Singh et al., 2009; Balamurugan et al., 2016). During 2011, the Government of India (https://www.dahd.nic.in) implemented a national control program on PPR (PPR-CP), in which the vaccination was covered in South peninsular India in the first phase, and the remaining states and union territories were included in the second phase from 2014 (Balamurugan et al., 2016, 2021). Since then, various programs have been taken care including mass vaccination, restricted nomadic movements, surveillance, focus vaccination, and quarantine of animals to control the spread of the disease. Despite vaccination, several outbreaks of PPR in sheep and goats are occurring and have not been recorded properly, owing to inadequate reporting of animal diseases in India. Moreover, neither systematic surveillance nor sero-monitoring was undertaken to assess the effectiveness of the vaccination in a particular region except for a few studies (Balamurugan et al., 2018, 2020b). The disease has been brought under control in some of the states and PPR outbreaks threat reported declined progressively and substantially in the continuous vaccination practiced states like Chhattisgarh (Balamurugan et al., 2018) and Southern peninsular region (Balamurugan et al., 2020b) and benefits outweigh the cost of a vaccination program (Govindaraj et al., 2019).
Flock or herd immunity, although may be used in a slightly different sense, basically refers to the proportion of immune individuals in a population that reduces the risk of infection to the susceptible individuals by the presence and proximity of immune individuals (Fine et al., 2011). This threshold flock /herd immunity of PPR is set to be about $70-80 \%$ in the global eradication of the strategy of PPR (OIE and FAO, 2015; Hammami et al., 2016). The proportion of immune animals which confer protection due to population immunity may vary depending on the contact structure of the population and transmissibility of the agent. The prevalence studies after PPR vaccination in small ruminants has been reported from different endemic countries in the world including India (Balamurugan et al., 2018, 2020b; Yirga et al., 2020).

The Odisha state implemented a mass vaccination, during the year 2015 in the second phase of the PPRCP implementation (Balamurugan et al., 2016, 2020a). However, despite the implementation of PPR-CP in Odisha, systematic epidemiological surveys for PPR for the state have not been conducted except for serosurvey during 2017-2018 (Balamurugan et al., 2020a), which showed 54.2\% prevalence of the PPRV antibodies in small ruminants population. Despite mass vaccination is being adopted, disease outbreaks with associated epidemiological factors are being reported sporadically in some places of Odisha state (Kumar et al., 2017; Mishra et al., 2020; Rath et al., 2020). Therefore, after regular implementing the vaccination program, the present serosurvey is being undertaken here along with the collection of host factors to establish the population immunity of PPR in sheep and goats at a given period to determine PPRV antibodies status towards the eradication of PPR in Odisha state.

\section{MATERIALS AND METHODS}

\section{STUDY AREA AND SAMPLING METHODS}

Odisha state is located in the eastern coastal part, surrounded by the states of Jharkhand, West Bengal, Chhattisgarh, and Andhra Pradesh, and the state has 6.5 million goats and 1.5 million sheep population, as per the $20^{\text {th }}$ livestock census, 2019 (http://www.dahd.nic.in). Serosurvey was conducted from $28^{\text {th }}$ January 2021 to $22^{\text {nd }}$ February 2021 and a multistage random sampling technique was followed to collect primary data from sheep and goat rearing farm households. In the first stage, all the districts of Odisha were classified as per the sheep and goat population density into high $(n=7)$, medium $(n=11)$, and low $(n=12)$ and one district from each category namely Mayurbanjh (high), medium (Balangir), and low (Kalahandi) was selected randomly. Further two blocks from each district and eight to ten villages from each block were selected randomly. In India, the village is distinct and considered as the epidemiological unit (epi-unit) in the studied Odisha 
state, as reported earlier (Balamurugan et al., 2020a). In the final stage, three to four households or flocks were selected randomly in each of the randomly selected villages in the survey.

Small ruminants samples ( $\mathrm{n}=363$ ) were collected randomly from 75 flocks in the selected three districts from the study area, along with the questionnaire data. The collected blood sample along with appropriate questionnaire information about the individual animal factors was labeled and transported in cold condition to the nearby local veterinary hospital for separation of serum and separated clear serum was transported to Indian Council of Agricultural Research -National Institute of Veterinary Epidemiology and Disease Informatics (ICAR-NIVEDI) and up on received stored at $-20{ }^{\circ} \mathrm{C}$ until the screening. The questionnaire data collection format contained information about the name of individual household farmer, demographic attributes, age, sex, breed, flock size, etc., and PPR control measures. The sampled primary surveyed villages in three districts in the Odisha state are depicted in GIS Map (Figure 1) of India based on their geo-coordinates using QGIS Software 2.18.6 version.

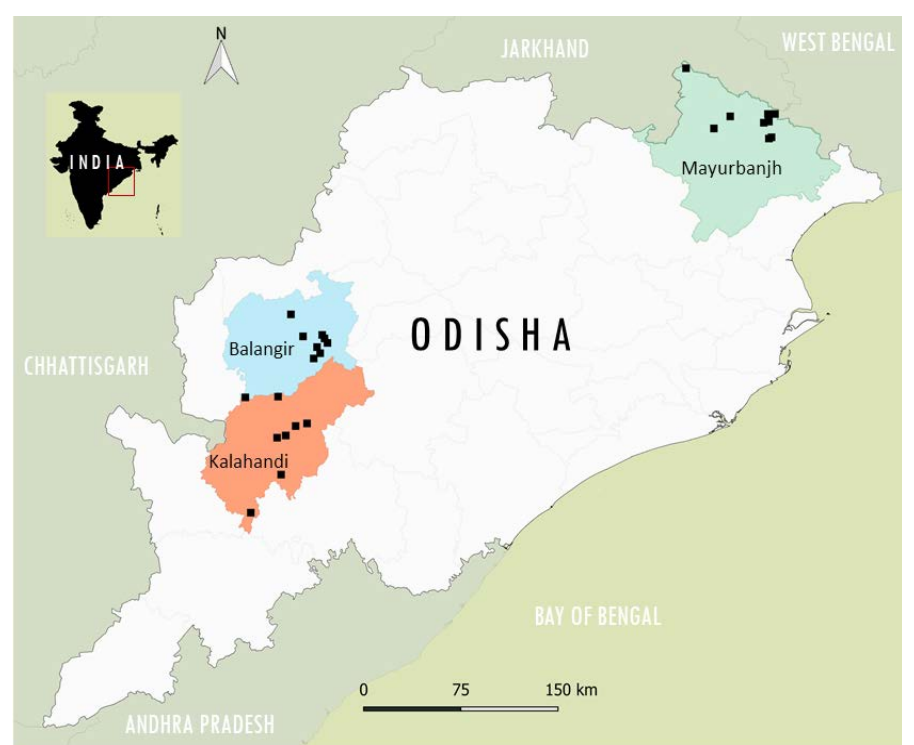

Figure 1: The surveyed epi-units (villages) in the district locations are depicted (as a square dot) in the GIS Map of the Odisha state in India.

\section{Sample TeSTing AND ANALYSiS}

All the collected serum samples were tested by an indigenously developed PPR competitive ELISA kit (the kits were purchased from the ICAR-Indian Veterinary Research Institute, Mukteshwar, campus, Nainital, Uttarakhand) according to (Singh et al., 2004) protocol Samples with a percentage inhibition (PI) of $>40 \%$ were considered as positive for the presence of PPRV specific antibodies and the overall percentage of seropositivity or seroprevalence was calculated with $95 \%$ confidence intervals
(CI). Field and laboratory parameters results were coded into appropriate variables and analyzed using Microsoft Office Excel 2016. The seroprevalence was estimated based on the number of positive animals versus the number of tested animals. Multivariable logistic regression analysis was carried out using " $R$ " version 4.0.2 software and was fitted with positivity or negativity of animals as dependent and age, species, gender, and districts as independent variables to understand the significant association of the host factors with the presence of PPRV antibodies in sheep and goats in the rural system of Odisha.

\section{RESULTS AND DISCUSSION}

The efficiency of vaccination programs or campaigns needs to be evaluated to achieve the eradication of PPR by the stipulated time frame. Post-vaccination evaluation of herd or flock and population immunity at the epi-unit levels enables evaluation of the immunogenicity of the vaccine and the efficiency of vaccine delivery (OIE and FAO, 2015). Evidence of the degree of the correlation between seroconversion and protection under field conditions may be needed to make appropriate inferences of population immunity.

Therefore, the present study assessed the status of PPRV antibodies in sheep and goats in the study area of Odisha as a part of the population immunity evaluation and generated evidence on the immune status, which is paramount important for devising further effective control strategies towards the eradication of PPRV. District-wise details of serum samples tested and their positivity for the PPRV antibodies are presented in Table 1. The results revealed that the observed prevalence of PPRV antibodies in small ruminants was 92.0, 72.2, and $50.7 \%$ in Balangir, Kalahandi, and Mayurbhanj districts, respectively in the studied region, with an overall $64 \%$ with $59.23 \%$ in sheep and $66.52 \%$ in goats, as regular vaccination is being practiced in all the districts of Odisha as per PPR-CP plan in both sheep and goats population. This post-vaccination immunity was lower than the recommended herd immunity threshold needed to control the transmission of the PPRV in a population. However, the level was higher than the seroconversion level of $61 \%$ reported fourteen days post-vaccination in Awash Fentale District of Afar region of Ethiopia (Faris et al., 2012). Further, the result was corroborated with district-wise prevalence study in Odisha, in which the seroprevalence of $48.42 \%$ in small ruminants with $44.7 \%$ in sheep and $51.21 \%$ in goats has been reported (Hota et al., 2018). Similarly, our previous study conducted at village levels during 2017-2018 (Balamurugan et al., 2020a) also showed $54.2 \%$ prevalence of the PPRV antibodies with significant association in the goats $\left(\right.$ Chi-square value $\left.\mathrm{x}^{2}=93.28, \mathrm{p}<0.01\right)$. 
Table 1: Details of the PPRV antibodies prevalence in small ruminants in the studied region of Odisha.

\begin{tabular}{|c|c|c|c|c|c|c|c|c|c|c|c|c|}
\hline \multirow[t]{2}{*}{$\begin{array}{l}\text { Name of } \\
\text { the district }\end{array}$} & \multirow[t]{2}{*}{$\begin{array}{l}\text { No. of the blocks } \\
\text { surveyed }\end{array}$} & \multirow[t]{2}{*}{$\begin{array}{l}\text { No. of the } \\
\text { village/ } \\
\text { epi unit } \\
\text { surveyed }\end{array}$} & \multirow[t]{2}{*}{$\begin{array}{l}\text { No. of } \\
\text { flocks } \\
\text { sur- } \\
\text { veyed }\end{array}$} & \multicolumn{3}{|c|}{$\begin{array}{l}\text { No. of samples } \\
\text { tested } \\
\text { (No. of samples } \\
\text { positive) }\end{array}$} & \multicolumn{3}{|c|}{$\begin{array}{l}\text { Apparent Prevalence of PPRV antibodies } \\
\text { status \% (Confidence Interval value at } 95 \% \text { ) }\end{array}$} & \multicolumn{3}{|c|}{$\begin{array}{l}\text { Percentage of } \\
\text { prevalence of } \\
\text { PPRV antibodies/ } \\
\text { Population immunity } \\
\text { number of epi units }\end{array}$} \\
\hline & & & & Sheep & Goat & Total & Sheep & Goat & Total & $<30$ & $30-70$ & $>70$ \\
\hline Balangir & $\begin{array}{l}2 \text { (Deogaon, } \\
\text { Saintala) }\end{array}$ & 9 & 11 & $\begin{array}{l}19 \\
(17)\end{array}$ & $\begin{array}{l}56 \\
(52)\end{array}$ & $\begin{array}{l}75 \\
(69)\end{array}$ & $\begin{array}{l}89.47 \\
(68.06-97.06)\end{array}$ & $\begin{array}{l}92.86 \\
(83.03-97.19)\end{array}$ & $\begin{array}{l}92.0 \\
(83.63-96.28)\end{array}$ & 0 & 0 & 9 \\
\hline Indi & $\begin{array}{l}2 \text { (Bhawanipatn, } \\
\text { Narla) }\end{array}$ & 9 & 23 & $\begin{array}{l}55 \\
(44)\end{array}$ & $\begin{array}{l}24 \\
(13)\end{array}$ & $\begin{array}{l}79 \\
(57)\end{array}$ & $\begin{array}{l}80.0 \\
(67.64-88.45)\end{array}$ & $\begin{array}{l}54.17 \\
(35.08-72.11)\end{array}$ & $\begin{array}{l}72.15 \\
(61.42-80.83)\end{array}$ & 0 & 3 & 6 \\
\hline $\begin{array}{l}\text { Mayur- } \\
\text { banjh }\end{array}$ & $\begin{array}{l}2 \text { (Bangiriposi, } \\
\text { Saraskan) }\end{array}$ & 10 & 41 & $\begin{array}{l}56 \\
(16)\end{array}$ & $\begin{array}{l}153 \\
(90)\end{array}$ & $\begin{array}{l}209 \\
(106)\end{array}$ & $\begin{array}{l}28.57 \\
(18.42-41.47)\end{array}$ & $\begin{array}{l}58.82 \\
(50.90-66.31)\end{array}$ & $\begin{array}{l}50.72 \\
(43.99-57.42)\end{array}$ & 3 & 6 & 1 \\
\hline Total & 6 & 28 & 75 & $\begin{array}{l}130 \\
(77)\end{array}$ & $\begin{array}{l}233 \\
(155)\end{array}$ & $\begin{array}{l}363 \\
(232)\end{array}$ & $\begin{array}{l}59.23 \\
(50.64-67.29)\end{array}$ & $\begin{array}{l}66.52 \\
(60.24-72.27)\end{array}$ & $\begin{array}{l}63.91 \\
(58.85-68.68)\end{array}$ & 3 & 9 & 16 \\
\hline
\end{tabular}

Table 2: Multivariable logistic regression analysis of the host factors with the presence of the PPRV antibodies in small ruminants in the studied region of Odisha.

\begin{tabular}{|c|c|c|c|c|c|}
\hline Variables & Variables & Estimates & Std. Error (SE) & Adjusted or (+-1.96\% CI) & $P=$ value \\
\hline Intercept & Intercept & 0.273 & 0.186 & -- & 0.141 \\
\hline \multirow[t]{2}{*}{ Age } & 6 to 12 Months & -0.223 & 0.251 & $0.80^{\mathrm{ns}}(-0.71,1.29)$ & \multirow[t]{2}{*}{0.373} \\
\hline & $>1$ years Adult & -- & -- & 1 & \\
\hline \multirow[t]{2}{*}{ Species } & Sheep & -0.610 & 0.267 & $0.54^{* *}(0.018,1.06)$ & \multirow[t]{2}{*}{0.021} \\
\hline & Goats & -- & -- & 1 & \\
\hline \multirow[t]{2}{*}{ Gender } & Male & -0.051 & 0.289 & $0.95^{\text {ns }}(-0.61,1.51)$ & \multirow[t]{2}{*}{0.858} \\
\hline & Female & -- & -- & 1 & \\
\hline \multirow[t]{3}{*}{ Districts } & Balangir & 2.424 & 0.453 & $11.30 * * *(1.53,12.19)$ & 0.000 \\
\hline & Kalahandi & 1.220 & 0.324 & $3.39^{* * *}(0.58,4.02)$ & 0.000 \\
\hline & Mayurbanjh & -- & -- & 1 & \\
\hline
\end{tabular}

Reference categories:1; Significance ${ }^{* * *}$ and ${ }^{* *}$ at $1 \%$ and 5\% level respectively. ns= Not-significant

Further, on multivariable logistic regression analysis, a significant difference was observed between species and across districts and not between age, sex, etc. The details of the test analysis according to conditional step-wise logistic regression, for host parameters compared to PPR sero-positivity are presented in Table 2. According to geographical region, the seroprevalence was higher in the Balangir, followed by Kalahandi and Mayurbanjh districts, with differences among studied areas, was statistically significant. Among species, the odds of presence of PPRV antibodies in sheep is significantly less than in goats $(\mathrm{OR}=0.54)$, as the state has a $1: 4.3$ ratio of sheep and goats population, as per the $20^{\text {th }}$ livestock census, 2019 . Similarly, the odds of the presence of PPRV antibodies were more in Balangir and Kalahandi districts by 11 and 3 times, respectively than in Mayurbanjh district, despite regular vaccination is being practiced, the variation in the immunity levels were also observed in the epi-unit level in the target population. Moreover, the results showed higher seropositivity in adults $(65.86 \%)$ compared to young animals $(59.65 \%)$ and in males $(68.89 \%)$ compared to females $(62.27 \%)$ without significance. These findings are concurrent with previous results that reported a liberal raise of prevalence with increasing age and related it (Muse et al., 2012), but contrast to the study of Özkul et al., (2002). Further, under one year old animals had lower seropositivity when compared to adult animals, this finding concurs with reported studies from Sudan and Kenya (Salih et al., 2014; Gitonga, 2015). Further, differences in PPRV seropositivity depending on species, sex, age, season, and geographical location have previously also been described (Mostafa and Elfadil, 2012).

In comparison with the previous study (Balamurugan et al., 2020a), an increase in the prevalence of PPRV antibodies to the tune of $10 \%$ in the population was observed, which might be due to the effects of the vaccination to attain the desired level of population immunity in the state., Moreover, the year-wise progress response to vaccination depends on the vaccination coverage and the efficacy of the vaccine at the field level. The state practiced 'focused vaccination' from 2004 as and when required for control of the outbreaks and in consonance with national PPR-CP, the state implemented a mass vaccination program during the year 2015-2016 with the different vaccination coverage over time (Balamurugan et al., 2020a), whereas the recent 
vaccination coverage of $77.72,94.88$ and $84.95 \%$ was achieved by the state animal husbandry department during 2018-2019; 2019-2020; and 2020-2021, respectively. In general, vaccination needs to be carried out to reach 70-80\% level immunity status in the state/region and further, the vaccination may be restricted to bordering districts, animal markets, and check posts only, in the absence of the occurrence of outbreaks. However, some sporadic outbreaks may experience in some pockets, where mixing of the infected/ vaccinated and non-vaccinated animals gathering especially in the local market during transportation for trade and during nomad migration of animals.

Moreover, the prevalence of PPRV antibodies indicates either the subclinical or naturally infected and recovered animals and has specific implications in epidemiological perspectives since it highlights the prevalence under the natural non-vaccination situation. By employing the PPR c-ELISA (Singh et al., 2004b), it is not possible to distinguish the immune response due to either vaccination or PPRV infection, as the vaccine or the test used in the PPR-CP in India did not differentiate between infected and vaccinated animals (DIVA). Further, the role of the exposure to the PPRV in the observed higher proportion of seropositivity cannot be ruled out, as seroconversion is used in post-vaccination evaluation tools to monitor the success of vaccination (OIE and FAO, 2015). However, the earlier population surveys in the non-outbreaks reported Chhattisgarh state and in a few sporadic outbreaks reported Andhra Pradesh, Telangana, and Karnataka states indicated seropositivity above $55 \%$, and the prevalence of PPRV antibodies, respectively implies vaccination is being implemented in the small ruminants population under the PPR-CP (Balamurugan et al., 2018, 2020b). Hence, the observed $64 \%$ prevalence of PPRV antibodies in the population indicates the population immunity level. The observed seropositivity level was concurrent to what has expected from post-vaccination evaluation status in Odisha, however, as the area is PPR endemic and risk zone, and animals are constantly being challenged with the virus either through natural infection or vaccination as reported earlier in northwest Ethiopia (Yirga et al., 2020). Therefore, seropositive animals and presumably many of the animals will be protected against future PPR outbreaks, though sporadic outbreaks are being reported in Odisha state. Moreover, overall, the higher PPR seropositivity was attributed to either access to government-funded PPR vaccination program or may be recovered infected animals.

Further, the observed seroconversion in sheep and goats was near to recommended levels by the OIE, that prevents virus circulation in endemic and high-risk areas (OIE and FAO, 2015). This indicates the PPR control vaccination strategy adopted has provided population immunity towards desired protection levels. The percentage prevalence of the PPRV antibodies in various epi-units is shown in Table 1 . The proportion of epi-units should have at least $70 \%$ of the seropositive population for protection and vaccine and vaccination efficacy in the field condition as per PPR-GCES guidelines (OIE and FAO, 2015), however, in the present study, $60 \%$ of the epi-units only had shown $70 \%$ prevalence level of PPRV antibodies, which implies further intensive vaccination coupled with active surveillance programs to make this region a PPR free zone. For that, the mass vaccination program needs to be adopted in line with the OIE eradication pathway of PPR control strategies, as per the national strategic plan for eradication of PPR 2025, for eradication of PPR from India (Balamurugan et al., 2021). Moreover, Fournie et al. (2018) estimated a permanent herd immunity as low as $37 \%$ was suggested to be enough to prevent a PPR outbreak or restrict the spread of the virus in an endemic setting by fitting a metapopulation simulation model of a pastoral area in Ethiopia for disease control. This estimate corresponded with the observed results of the present study in Odisha (only three villages in Mayurbanjh district out of 28 villages /epi-units tested had only < $37 \%$ prevalence), which showed the limited restricted spread of the virus in the state, as there were only a few sporadic outbreaks have been reported recently from Odisha (Kumar et al., 2017; Rath et al., 2020) including a few outbreaks reported from Cuttack and Khordha districts during 2020 and Kendrapara, Cuttack, and Nayagarh districts during March and April 2021 reported from Odisha as per outbreaks data obtained from state animal husbandry departments, Odisha (https://www.nivedi.res.in/Nadres_v2/).

In general, the difficulty of maintaining an effective cold chain in remote rural areas and poor vaccine delivery can compromise the development of sufficient herd immunity in the vaccinated population (Yirga et al., 2020). Moreover, small ruminant populations are characterized by rapid turnover due to lambing/kidding, fecundity of animals, slaughter and sales of animals, etc., and this dynamic population turnover including the appearance of newborns animals may rapidly reduce the herd immunity acquired from vaccination programs upsetting efforts at controlling the disease. However, population turnover could vary in different seasons of the year and the timing of vaccination in relation to this seasonality of population turnover may have a critical impact on the maintenance of herd immunity in the inter-vaccination period (Hammami et al., 2016). High seroconversion was found with the flocks tested indicating a good herd immunity level for PPR, a finding consistent with reports from other states of the country as well as from other countries. However, to determine exactly the proportion of immune animals in the 
flocks or villages, after six to eight months after vaccination needs to be studied due to the impact of the sheep and goats dynamic population turnover along with optimizing vaccine schedules in the program with the frequency and timing of vaccination to maintain herd immunity.

\section{CONCLUSIONS AND RECOMMENDATIONS}

The present survey provides information on the status of PPRV antibodies in sheep and goats and associated possible host factors with the variation in the immunity levels observed in the epi-unit level in the studied areas. This generated population immunity of $64 \%$ evidence as a part of the post vaccination evaluation is paramount important for devising further effective control strategies towards the eradication of PPR. Hence, to achieve the desired cluster level immunity as envisaged in PPR-CP, the timely mass vaccination program in the designated period is to be carried out continuously to reach a 70-80\% herd level immunity status. Then, vaccination may be restricted to bordering districts, animal markets, and check posts only, to avoid circulation of PPRV among sheep and goats, to protect small ruminants from PPRV infection without the occurrence of sporadic outbreaks to improve animal and farmers welfare. The study also implies that the small ruminants population in only a few of the epi-units in the studied region were having less than $30 \%$ seroprevalence, which necessitates further intensive vaccination and active surveillance programs to make PPR-free zone of Odisha within the stipulated period as per the national strategic plan for PPR eradication. Therefore, zoning the PPR risk regions and initiating vaccination at a specified period with complete vaccination coverage of all the risk populations in the identified zone is of paramount importance along with monitoring and surveillance.

\section{ACKNOWLEDGMENTS}

The authors wish to thank the Indian Council of Agricultural Research (ICAR), New Delhi, India, and the ICAR-NIVEDI for constant support and encouragement always. This work was carried out with funding support from the DST project "Disease burden quantification in small ruminants and impact of adopting preventive interventions on rural livestock farmers in Odisha" (F. No. DST/SSTP/2018/425 dt. 20.8.2019. The authors also thank the ICAR-NIVEDI staff for their continuous support and timely help to execute the research work. The authors also wish to thank the Odisha Animal Husbandry and Veterinary Sciences Department, ADRI, Cuttack, field Veterinarians, and animal health assistants for their kind help during investigations and collection of samples.

\section{NOVELTY STATEMENT}

Assessed the PPRV antibodies prevalence/population immunity status with host factor determinants in sheep and goats at epidemiological unit/village level in Odisha.

\section{AUTHOR'S CONTRIBUTION}

SSK carried out the experiments and wrote the rough draft of the manuscript. GB and BM Collected and transported samples to NIVEDI. KVK and GG interpreted the data and performed the statistics. NM, SSJ designing of the sampling plan. NM, SSJ, and GG language editing of the MS. BRS provided guidance and support to carry out the research work. VB designed and conceptualized the experiment, interpreted the data, and rewritten the draft, and edited the manuscript. All authors read and approved the final manuscript.

\section{COMPLIANCE WITH ETHICAL STANDARDS}

\section{STATEMENT OF ANIMAL RIGHTS}

The manuscript does not contain animal experimental trials. No ethical clearance is required for collecting small volumes of blood samples required for seroepidemiological studies, as per CPCSEA (Committee for the Purpose of Control and Supervision of Experiments on Animals) guidelines. Moreover, the serum samples were collected by well-trained veterinarians concerning animal welfare regulations for the diagnosis of disease

\section{CONFLICT OF INTEREST}

The authors have declared no conflict of interest.

\section{REFERENCES}

- Balamurugan V, Govindaraj GN, Rahman H (2016). Planning, implementation of peste des petits ruminants control programme and strategies adopted for disease control in India. Br. J. Virol., 3(3s): 53-62. https://doi.org/10.17582/ journal.bjv/2016.3.3s.53.62

- Balamurugan V, Hemadri D, Gajendragad MR, Singh RK, Rahman H (2014). Diagnosis and control of peste des petits ruminants: a comprehensive review. Virus Dis., 25(1): 3956. https://doi.org/10.1007/s13337-013-0188-2

-Balamurugan V, Kumar KV, Dheeraj R, Kurli R, Suresh KP, Govindaraj GN, Shome BR, Roy P (2021). Temporal and spatial epidemiological analysis of peste des petits ruminants outbreaks from the past 25 Years in sheep and goats and its control in India. Viruses, 13(3): 480-480. https://doi. org/10.3390/v13030480

- Balamurugan V,Muthuchelvan D, Govindaraj G,Roy G, Sharma V, Sowjanya Kumari S, Choudhary Dheeraj, Mohanty BS, Suresh KP, Rajak KK, Hemadri D, Roy P (2018). Serosurvey for assessing PPR vaccination status in rural system of Chhattisgarh state of India. Small Rumin. Res., 165(6450): 87-92. https://doi.org/10.1016/j.smallrumres.2018.05.011 -Balamurugan V, Saravanan P, Sen A, Rajak KK, Bhanuprakash V, 
Krishnamoorthy P, Singh RK (2011). Sero-epidemiological study of peste des petits ruminants in sheep and goats in India between 2003 and 2009. Rev. Sci. Tech. OIE, 30(3): 889-896. https://doi.org/10.20506/rst.30.3.2087

- Balamurugan V, Varghese B, Muthuchelvan D, Kumar KV, Govindaraj G, Suresh KP, Kumar Pankaj, Hemadri D, Roy Parimal (2020a). Seroprevalence of peste des petits ruminants in sheep and goats in Eastern India. Virus Dis., 31(3): 383-387. https://doi.org/10.1007/s13337-02000574-2

- Balamurugan V, Varghese B, Muthuchelvan D, SowjanyaKumari S, Kumar KV, Dheeraj R, Govindaraj G, Suresh KP, Hemadri D, Roy P (2020b). Towards eradication of peste des petits ruminants: post-vaccination evaluation in sheep and goats in Southern Peninsular India. Virus Dis., 31(4): 539-548. https://doi.org/10.1007/s13337-020-00630-x

-Faris D, Yilkal A, Berhe G, Kelay B (2012). Seroprevalence and sero-conversion after vaccination against Peste des Petits Ruminants in sheep and goats from Awash Fentale District, Afar, Ethiopia. Prev. Vet. Med., 103(2-3): 157-162. https:// doi.org/10.1016/j.prevetmed.2011.10.007

-Fine P, Eames K, Heymann DL (2011). Herd immunity: A rough guide. Clin. Infect. Dis., 52(7): 911-916. https://doi. org/10.1093/cid/cir007

-Fournié G, Waret-Szkuta A, Camacho A, Yigezu ML, Pfeiffer UD, Roger F (2018). A dynamic model of transmission and elimination of peste des petits ruminants in Ethiopia. Proc Natl Acad Sci 115:8454-8459. https://doi.org/10.1073/ pnas. 1711646115

- Gitonga P (2015). Spatial analysis of risk factors and their effects on peste des petits ruminants control strategies in Kajiado and Marsabit pastoral systems of Kenya.

- Govindaraj GN, Roy G, Mohanty BS, Balamurugan V, Pandey AK, Sharma V, Patel A, Mehra M, Pandey SK, Roy P (2019). Evaluation of effectiveness of Mass Vaccination Campaign against Peste des petits ruminants in Chhattisgarh state, India. Transbound. Emerg. Dis., 66(3): 1349-1359. https:// doi.org/10.1111/tbed.13163

-Hammami P, Lancelot R, Lesnoff M (2016). Modelling the dynamics of post-vaccination immunity rate in a population of sahelian sheep after a vaccination campaign against peste des petits ruminants virus. PLoS One, 11(9): e0161769. https://doi.org/10.1371/journal.pone.0161769

- Hota A, Biswal S, Sahoo N, Rout M, Chaudhary D, Pandey A, Muthuchelvan D (2018). Seroprevalence of PPR among Sheep and Goats of Different Agroclimatic Zones of Odisha. Int. J. Livest. Res., 8(4): 296-302. https://doi. org/10.5455/ijlr.20171028023420

- Kumar P, Sinha B, Roy RK, Kumari RR, Kumar A (2017). Peste-des-petits-ruminants in goats: Sero-epidemiological study in middle Indo-Gangetic plains. Indian J. Anim. Sci., 87(4): 418-421.

-Mishra AR, Rath PK, Panda SK, Nayak D (2020). Influence of mutation in nucleoprotein of Peste-des-petits-ruminants virus (PPRV) isolated from 2016 Indian outbreak. Small
Rumin. Res., 184(March): 106048-106048. https://doi. org/10.1016/j.smallrumres.2020.106048

-Mostafa ETSA, Elfadil AAM (2012). Sero-prevalence and risk factors of pesre des petitss ruminants (PPR) in sheep in river Nile and White Nile States, Sudan. J. Vet. Med. Anim. Prod., 3: 106-126.

- Muse EA, Karimuribo ED, Gitao GC, Misinzo G, Mellau LSB, Msoffe PLM, Swai ES, Albano MO (2012). Epidemiological investigation into the introduction and factors for spread of Peste des Petits Ruminants, southern Tanzania. Onderstepoort J. Vet. Res., 79(2): 457. https://doi. org/10.4102/ojvr.v79i2.457

- OIE, FAO (2015). Manual on global strategy for the control and eradication of Pesti des petits ruminants. (http://www. fao.org/3/a-i4460e.pdf).

- Özkul A, Akca Y, Alkan F, Barrett T, Karaoglu T, Dagalp SB, Anderson J, Yesilbag K, Cokcaliskan C, Gencay A, Burgu I (2002). Prevalence, Distribution, and Host Range of Peste des petits ruminants virus, Turkey. Emerg. Infec. Dis., 8(7): 709-712. https://doi.org/10.3201/eid0807.010471

- Ragavendra AG, Gajendragad MR, Sengupta PP, Patil SS, Tiwari CB, Balumahendiran M, Sankri V, Prabhudas K (2008). Seroepidemiology of peste des petits ruminants in sheep and goats of southern peninsular India. Rev. Sci. Tech. OIE, 27(3): 861-867. https://doi.org/10.20506/ rst.27.3.1838

-Rath PK, Panda SK, Mishra BP, Karna DK, Sahoo G, Mishra UK, Patra RC (2020). Epidemiological risk factor analysis in goats and sheep naturally infected with Peste des petits ruminants virus. J. Entomol. Zool. Stud., 8(3): 546-549.

-Salih HAM,Elfadil AM,Saeed K,Ali YH(2014). Seroprevalence and risk factors of Peste des Petits Ruminants in sheep and goats in Sudan. J. Adv. Vet. Anim. Res., 1(2): 42-49. https:// doi.org/10.5455/javar.2014.a12

-Singh R, Balamurugan V, Bhanuprakash V, Sen A, Saravanan P, Pal Yadav M (2009). Possible control and eradication of peste des petits ruminants from India: Technical aspects. Vet. Ital., 45(3): 449-462.

- Singh RP, Saravanan P, Sreenivasa BP, Singh RK, Bandyopadhyay SK (2004a). Prevalence and distribution of peste des petits ruminants virus infection in small ruminants in India. Rev. Sci. Tech. OIE, 23(3): 807-819. https://doi.org/10.20506/ rst.23.3.1522

-Singh RP, Sreenivasa BP, Dhar P, Shah LC, Bandyopadhyay SK (2004b). Development of a monoclonal antibody based competitive-ELISA for detection and titration of antibodies to peste des petits ruminants (PPR) virus. Vet. Microbiol., 98(1): 3-15. https://doi.org/10.1016/j.vetmic.2003.07.007

-Yirga A, Jemberu WT, Lyons N, Gebru A, Akililu F, Rushton J (2020). Post-vaccination herd immunity against peste des petits ruminants and inter-vaccination population turnover in small ruminant flocks in northwest Ethiopia. Prev. Vet. Med., 174: 104850. https://doi.org/10.1016/j. prevetmed.2019.104850 